$10: 14-27)$ in postexilic Jerusalem. They are all presented as having made a written binding promise to follow the Torah of God given through Moses (Neh 10:29). Apart from this mention, nothing more is known of Bilgai. It may be that Bilgai is the same person named Bilgah (also a priest) in Neh 12:5, 18 .

\section{Gordon Wong}

See also $\rightarrow$ Bilgah

\section{Bilhah (Person)}

I. Hebrew Bible/Old Testament

II. Judaism

\section{Hebrew Bible/Old Testament}

Bilhah (MT Bilhâ) was the servant of Rachel (Gen $30: 3$ ), who became Jacob's third wife (Gen 30:4) and mother of his sons Dan and Naphtali (Gen $30: 6,8)$.

Rachel's father, Laban, gave Bilhah to Rachel when Rachel married Jacob (Gen 29:29). When Rachel was unable to bear children, she gave Bilhah to Jacob so that she might have children through her. Rachel was responsible for naming Bilhah's sons. This surrogate motherhood arrangement is similar to that of other biblical women. Likewise, Sarai gave Hagar to Abram, and Hagar bore Ishmael (Gen 16:2, 15). In addition, when Leah gave Zilpah to Jacob, Zilpah bore Gad and Asher (Gen 30:913). This type of adoption practice is mentioned in the Nuzi documents.

After the death of Rachel, Reuben, the firstborn son of Jacob and Leah, had intercourse with Bilhah (Gen 35:22); as a result, Reuben's birthright was revoked and given to Joseph's sons (Gen 49:3-4; 1 Chr $5: 1)$.

Nyasha Junior

\section{Judaism}

According to the Testament of Naphtali, Bilhah was the daughter of Rotheos, a brother of Deborah, Rebekah's nurse and younger sister of Zilpah. Her mother was Aina, a servant girl (T.Naph. 1:9-11; see also Jub. 28:9). Another tradition, however, maintains that Bilhah was actually Rachel's paternal half sister: she and Zilpah were the daughters of Laban from another wife, but since he favored Leah and Rachel, he called Bilhah and Zilpah handmaidens (MidAg Gen 30:2; BerRbti p. 119).

Explanations of her name are based on its root $b$ - $h-l$ which can connote either haste or panic. According to one opinion, she was eager for new things and therefore hastened to nurse immediately after she was born (T.Naph. 1:12; cf. BerRbti, p. 119). Another midrashic tradition records that she was named Bilhah because when she was born she was frightened (hayetah mitbahelet) and could not nurse properly (MidAg, Gen. 30:2).

The blame for the incident with Reuben (Gen $35: 22$ ) is placed squarely on the latter's shoulders. According to the Testament of Reuben, Reuben saw Bilhah bathing and was attracted to her (cf. David and Bathsheba: 2 Sam 11:2). While Bilhah was drunk and naked, Reuben slept with her. She was unaware of the assault, but an angel revealed to Jacob what had happened; henceforth he refrained from sexual contact with Bilhah (T. Reu. 3:11-15). In the book of Jubilees, Bilhah awakens to find Reuben in her bed after he has raped her $(33: 4)$, and she tells Jacob what happened (33:6-7). Rashi (ad Gen $35: 22$ ), following the Talmud (bShab 55b), explains that Reuben was trying to defend his mother's honor, since, after Leah's death, Jacob had moved his bed into Bilhah's tent. To show his displeasure, he disturbed her bed, but did not actually sleep with her. According to Radaq (ad loc.), however, though Bilhah was Jacob's wife to all intents and purposes, Reuben still considered her a maidservant and therefore permitted to him.

After Rachel's death, Bilhah raised her children, Joseph and Benjamin, as her own (BerR 84:11).

While the dominant tradition seems to be that Israel has three patriarchs and four matriarchs (see bBer 16b), a number of rabbinic sources count Bilhah and Zilpah among the matriarchs as well (e.g., BemR 12:17, EstR 1:12, ShirR 6.4.2). In recent times, the rise of the feminist movement has led among non-Orthodox movements to the inclusion in the liturgy of the matriarchs of Israel along with the patriarchs (e.g., in the first blessing of the Amidah, or in the "Blessings after Meals"). There has been considerable discussion in some of these circles around the inclusion of Bilhah and Zilpah along with Sarah, Rebekah, Rachel, and Leah. While most lists of the matriarchs in egalitarian siddurim still do not include them, on the grounds that they do not have the same status in the tradition as the other four (kabbalistic sources explain this in deeper, mystical terms), or that their children were adopted by Leah and Rachel (the adoption derash; see Mark), one prayerbook that does is Siddur B'chol l'vav'cha, published by the New York LGBT synagogue Beit Simchat Torah, a community which is especially sensitive to issues of disenfranchisement and inclusion. It remains to be seen whether this innovation will gain wider acceptance.

Bibliography: - Congregation Beth Simchat Torah, Siddur Bechol levavcha: With All Your Heart (New York 2008). [Esp. 106] - Halpern-Amaru, B., "Bilhah and Naphtali in Jubilees: A Note on 4QTNaphtali,” DSD 6 (1999) 1-10. Halpern-Amaru, B., The Empowerment of Women in the Book of Jubilees (JSJ Supplement 60; Leiden 1999). [Esp. 103-33] - Mark, E. W., "The Four Wives of Jacob: Matriarchs Seen and Unseen," The Reconstuctionist 63/1 (1998) 22-36. [Available at www.rrc.edu; accessed December 16, 2010] - Rosen-Zvi, I., "Bilhah the Temptress: The Testament of Reu- 
ben and 'The Birth of Sexuality'," JQR 96 (2006) 65-94. - Stone, M. E., “The Genealogy of Bilhah,” DSD 3 (1996) 2036. -Weinstein, B., "Why Exclude Bilhah and Zilpah?," Journal of the Central Conference of the American Rabbis 57/1 (2010) 92-99.

Barry Dov Walfish

\section{Bilhah (Place)}

A location in Simeon (MT Bilhâ; $1 \mathrm{Chr} 4: 29)$ also called Baalah (Josh $15: 29)$ and Balah (Josh 19:3). It may be the same location as Baalath (Josh 19:44).

Nyasha Junior

\section{Bilhan}

There are two persons named Bilhan (MT Bilhān) in the $\mathrm{HB} / \mathrm{OT}$.

\section{Son of Ezer}

Bilhan is the name of one of the sons of Ezer who was a descendent of Seir the Horite in Edom (Gen $36: 27)$. He is also listed in the parallel genealogy in $1 \mathrm{Chr} 1: 42$. The Genesis list of Seir's sons is inclusive and very methodical, while the Chronicler's list is concise and merely a framework of names.

\section{Son of Jediael}

Bilhan is the firstborn son of Jediael and thus grandson of Benjamin, according to the genealogical clan list in $1 \mathrm{Chr} 7: 10$. He fathered Jeush, Benjamin, Ehud, Chenaanah, Zethan, Tarshish, and Ashishahar (cf. Gen 46:21; Num 26:38). This census registry may actually be for the tribe of Zebulun, since the Benjaminite list repeats with slight differences in 1 Chr $8: 1-40$.

Bibliography: - Japhet, S., I and II Chronicles (OTL; Philadelphia, Pa. 1993).

Craig Bowman

\section{Bill}

$\rightarrow$ Divorce

\section{Billerbeck, Paul}

Ernst Friedrich Paul Billerbeck (1853-1932) was born on April 4, 1853 in Schönfließ, now Trzcinsko Zdroj, Poland, as son of a farmer. He went to school in Schönfließ, then in Königsberg/Neumark, and studied theology in Greifswald and Leipzig. Among his teachers were Julius Wellhausen, Hermann Cremer and Franz Delitzsch. Ordained in 1879, he first became a curate in Wintershagen and then a parson in Zielenzig, now Sulecin (Poland). Having to care for a family with nine children, he moved in 1889 to Heinersdorf, now Drogomin (Poland), where he was also responsible for the pastoral work in Trebow and Schmagorei. In 1915 he retired and moved to Frankfurt a.d.O., where he died on December 23, 1932.

During his years at Heinersdorf he wrote about Jewish subjects, like "Abrahams Leben und Bedeutung für das Reich Gottes nach der älteren Haggada," "Eine Jüdische Paradiesschilderung," "Hat die alte Synagoge einen praeexistenten Messias gekannt?”. We do not know where Billerbeck's interest in Jewish subjects came from, how he learned to read rabbinic texts or how he was able to collect them. All his articles were published from 1899 to 1918 in the journal Nathanael: Zeitschrift für die Arbeit der evangelischen Kirche an Israel, edited by Hermann L. Strack. On account of them Strack urged Billerbeck to write a theology of the Talmud. But he was only willing to collect rabbinical parallels to the NT. The result was the Kommentar zum Neuen Testament aus Talmud und Midrasch (4 vols., München 1922-28). This commentary is still called "StrackBillerbeck," although Billerbeck was its only author. It has become the most important repository of rabbinic and earlier Jewish texts which can help in the understanding of the NT. Its abuse as a shortcut to the Jewish sources out of context has been rightly criticized. But used critically as a collection of texts to be studied in their wider context and ideally in their original languages, it is still of the greatest value.

In 1923 he became Doctor honoris causa of the University of Greifswald; the University of Königsberg also awarded him an honorary doctorate. He was buried in Heinersdorf, now Drogomin, but the cemetery is decayed and it is impossible to find his grave.

Bibliography: -Jeremias, J., "Paul Billerbeck in memoriam,” Theologische Blätter 12/2 (1933) 33-36. - Jeremias, J., “Billerbeck, Paul (1853-1932)," TRE 6 (Berlin/New York 1980) 640-42.

Julia Männchen

\section{Bilqīs}

$\rightarrow$ Sheba, Queen of

\section{Bilshan}

Bilshan (MT Bilšān; Ezra 2:2; Neh 7:7) was one of the leaders who returned to Jerusalem from Babylon with Zerubbabel. In 1Esd 5:8 he is called "Beelsarus." His name is possibly an abbreviated form derived from the Akkadian Bel-šunnu. Bilshan's precise leadership role and the nature of the list of returnees in these parallel texts are unknown.

Craig Bowman 